\title{
HIGH-ENERGY DIET AT ANTEPARTUM DECREASES INSULIN RECEPTOR GENE EXPRESSION IN ADIPOSE TISSUE OF POSTPARTUM DAIRY COWS
}

\author{
ZHIGANG ZHANG, JIANGUO WANG ${ }^{1}$, RUIFENG GAO ${ }^{1}$, WEIQIAN ZHANG, XINWEI LI ${ }^{1}$, \\ GUOWEN LIU ${ }^{1}$, XIAOBING LI $^{1}$, ZHE WANG ${ }^{1}$, AND XINGLIN ZHU ${ }^{1}$ \\ College of Veterinary Medicine, Northeast Agricultural University, Harbin, 150030, China \\ ${ }^{1}$ College of Veterinary Medicine, Jilin University, Changchun, 130062, China \\ wangzhe500518@sohu.com
}

Received: September 27, 2012

Accepted: May 15, 2013

\begin{abstract}
The objective of the study was to determine expression of gene of insulin receptor (INSR) in adipose tissue of postpartum dairy cows fed diets containing different amounts of energy at the antepartum period. Healthy pregnant dairy cows $(\mathrm{n}=45)$ on $21^{\text {st }} \mathrm{d}$ of the antepartum were divided into three groups differing in diet composition, namely: control group fed a normal diet, high energy group fed a high energy diet, and low energy group fed a low energy diet. Twenty-one days after parturition, INSR gene expression in adipose tissue was determined by internally controlled reverse transcriptase PCR. The level of INSR mRNA in adipose tissues of cows fed the high energy diet was substantially lower than that in cows fed normal or low energy diets. A relatively higher level of INSR mRNA in the adipose tissue of cows fed low energy diet may be beneficial for gluconeogenesis and lipogenesis, which can relieve an energy negative balance. Reduced level of INSR mRNA in adipose tissue of cows fed high energy diet indicates that the response to insulin has significantly decreased.
\end{abstract}

Key words: dairy cows, adipose tissue, insulin receptor, high energy diet, gene expression.

A major physiological characteristics of peripartum cows (the last 3 weeks before parturition and the first 3 weeks of lactation) is negative energy balance (NEB) (1). Dairy cows need to mobilise adipose tissue to compensate the relative deficit of glucose during the peripartum period, which is due to the NEB concomitant with the onset of lactation $(3,17)$. The rapid adaptation of key metabolic pathways is crucial to successfully undergo the transition from pregnancy to lactation (6). A failure for the adequate adaptation, may result in energy imbalances, leading to an increased risk of digestive, metabolic, or infectious disorders (e.g. displaced abomasum, retained placenta, ketosis, fatty liver, or mastitis) $(2,12)$, or even to a combination of disorders.

Insulin is a peptide hormone that initiates its biological effects by binding to specific insulin receptor (INSR) and activating it. This results in tyrosine phosphorylation of several substrates, including INSR substrate proteins (16). In addition to its functions in the liver, insulin also stimulates the synthesis and storage of fat, inhibits fat breakdown, and promotes glucose utilisation in adipose tissue (14). A reduction of INSR expression in early lactation participates in the development of NEB in dairy cows.

It is very important to understand the mechanisms underlying metabolic adaptations of early lactation, as well as development of new strategies to optimise health and well-being of early lactating dairy cows (22). Regulation of energy intake may be an effective method for relieving NEB in dairy cows during early lactation (7). In the study, the effect of a high energy diet during the antepartum period on INSR gene expression in adipose tissue of postpartum dairy cows was investigated.

\section{Material and Methods}

Healthy Chinese Holstein pregnant dairy cows $(n=45)$ were selected, and divided into three equal groups. The cows were 3-5-years of age, with 1-3 parities and mean body weight of $643 \mathrm{~kg}$, and their initial body condition score were similar amongst the groups. As shown in Table 1, cows in control group were fed according to the Dairy Cows Breeding Standard of China (2000), the high energy group was fed $20 \%$ above the nutritional requirement $(120 \%)$, and the low energy group was fed $80 \%$ of the nutritional requirement. The cows were housed in tie stalls individually. The experimental period was from day 21 antepartum to day 21 postpartum. After parturition, all cows were fed according to the Dairy Cows Breeding 
Standard of China (2000), with ad libitum intake.

On day 21 postpartum, a subcutaneous adipose tissue (50-80 mg) was obtained from cows by biopsy at the caudation. All samples were washed with sterile saline, snap-frozen in liquid nitrogen, and stored at $-80^{\circ} \mathrm{C}$. The experimental procedure was approved by the Academic Committee of Jilin University.

Primer design and DNA fragment amplification were performed as previously described $(12,13)$. Total RNA from adipose tissue was isolated using a Trizol RNA purification kit in accordance with the manufacturer's instructions. Isolated RNA was diluted 40 times and analysed spectrophotometrically at 260 and $280 \mathrm{~nm}$. Only samples with $\mathrm{OD}_{260 \mathrm{~nm}} / \mathrm{OD}_{280 \mathrm{~nm}}>1.9$ were retained for further analysis (24). Synthesis of cDNA and internally controlled RT-PCR were performed as previously described for detection of the INSR mRNA
$(12,13)$. Image processing and grey-scale analysis were performed with the TANLON gel image analysis system (Shanghai, China).

Concentrations of glucose and non-esterified fatty acids (NEFA) in serum were determined using commercially available kit (Nanjing Jian Cheng Institute of Bioengineering, China). Serum concentrations of $\beta$-hydroxybutyrate (BHBA) were measured by BHBA kit (Randox, United Kingdom). These assays were analysed using a Hitachi 7170 auto-analyser.

Data are presented as mean values and standard deviations (SD). Statistical significance was determined using one-factor analysis of variance followed by Duncan's least significant difference post-hoc test. The statistical package SPSS for Windows (version 18.0; SPSS, Chicago, USA) was used for statistical analysis. $\mathrm{P}<0.05$ was considered as statistically significant.

Table 1

Nutritional composition of the diet of different groups

\begin{tabular}{|c|c|c|c|c|}
\hline \multirow{3}{*}{ Ingredient } & \multicolumn{4}{|c|}{ Ratio of raw materials } \\
\hline & \multicolumn{3}{|c|}{ Antepartum } & \multirow{2}{*}{ Postpartum } \\
\hline & $\mathrm{C}$ & $\mathrm{H}$ & $\mathrm{L}$ & \\
\hline Supplement feed as concentrate (\%): & 60.76 & 60.62 & 49.47 & 52.72 \\
\hline Corn & 17.13 & 16.3 & 15.11 & 27.06 \\
\hline Bean meal & 0.0 & 0.0 & 0.0 & 4.92 \\
\hline Cottonseed meal & 1.0 & 2.0 & 0.0 & 2.0 \\
\hline Bean oil & 0.0 & 1.98 & 0.0 & 1.96 \\
\hline Plumery powder & 13.96 & 11.04 & 27.77 & 5.84 \\
\hline Wheat bran & 4.15 & 4.06 & 4.15 & 0.0 \\
\hline Sunflower meal & 1.0 & 1.0 & 1.5 & $1 \cdot 0$ \\
\hline Brushite & 1.0 & 1.0 & 1.0 & 1.0 \\
\hline Compound additive premix & 0.0 & 1.0 & 0.0 & 1.0 \\
\hline Rocks powder & 1.0 & 0.8 & 1.0 & 1.0 \\
\hline Gravy salt & 0.0 & 0.2 & 0.0 & 1.5 \\
\hline Baking soda & 60.76 & 60.62 & 49.47 & 52.72 \\
\hline \multicolumn{5}{|l|}{ Roughage (\%) : } \\
\hline Corn silage & 15.16 & 15.43 & 16.24 & 45.28 \\
\hline Beet dregs & 12.11 & 24.67 & 0.0 & 20.9 \\
\hline Goat grass & 72.73 & 59.9 & 83.76 & 33.82 \\
\hline Ratio of concentrate to roughage & $37.53: 62.47$ & $42.83: 57.17$ & $34.04: 65.96$ & $43.78: 56.22$ \\
\hline \multicolumn{5}{|l|}{ Nutrient intake of $650 \mathrm{~kg}$ dairy cows } \\
\hline Energy units of dairy cows (NND/d, per cow) & 21.2 & 25.43 & 17.1 & 30.9 \\
\hline Dry matter (kg/d, per cow) & 11.89 & 12.76 & 10.5 & 22.98 \\
\hline Crude protein (g/d, per cow) & $1,117.0$ & $1,353.0$ & 908.7 & $2,895.0$ \\
\hline Crude fibre (g/d, per cow) & $2,818.0$ & $2,736.0$ & $2,675.0$ & $4,551.0$ \\
\hline Calcium (g/d, per cow) & 48.05 & 56.8 & 40.28 & 142.4 \\
\hline Phosphours (g/d, per cow) & 44.9 & 52.45 & 37.44 & 101.2 \\
\hline
\end{tabular}

C - control group; L - low energy diet group; H - high energy diet group 


\section{Results}

Based on the grey-scale analysis, the ratio of the grey-level between the PCR products of IR and the $\beta$-actin genes indicated the relative changes in expression of the IR gene in the tested samples (23). As shown in Table 2 and Fig. 1, there was a significant difference in gene expression among the three groups. INSR expression was reduced in the adipose tissue of cows fed a high energy diet compared with the control group $(\mathrm{P}<0.05)$. Moreover, INSR mRNA levels in adipose tissues of cows fed the low energy diet were the highest among the three groups. Serum glucose and NEFA of cows fed high energy diet were higher than that of other groups. There was no difference in serum BHBA between cows from control group and low energy diet group, but there were significant differences when they were compared with a high energy diet group.

Table 2

Effect of different energy diet on INSR mRNA levels in adipose tissue of cows on day 21 postpartum (mean \pm SD)

\begin{tabular}{cccc}
\hline \multirow{2}{*}{ Index } & \multicolumn{3}{c}{ Groups } \\
\cline { 2 - 4 } & $\mathrm{C}$ & $\mathrm{L}$ & $\mathrm{H}$ \\
\hline INSR mRNA abundance relative to $\beta$-actin & $0.65 \pm 0.05^{\mathrm{a}}$ & $0.78 \pm 0.1^{\mathrm{b}}$ & $0.54 \pm 0.02^{\mathrm{c}}$ \\
\hline
\end{tabular}

${ }^{\mathrm{a}, \mathrm{b}, \mathrm{c}}$ Mean values within a line with unlike superscript letters were significantly different $(\mathrm{n}=15, \mathrm{P}<0.05)$. $\mathrm{C}-\mathrm{control}$ group; L - low energy diet group; H - high energy diet group

Table 3

Effect of different energy intake on serum glucose, NEFA, and BHBA of dairy cows on day 21 postpartum (mean \pm SD)

\begin{tabular}{cccc}
\hline Index & \multicolumn{3}{c}{ Groups } \\
& $\mathrm{C}(\mathrm{n}=15)$ & $\mathrm{L}(\mathrm{n}=15)$ & $\mathrm{H}(\mathrm{n}=15)$ \\
\hline Glucose $(\mathrm{mM})$ & $3.6 \pm 0.22^{\mathrm{a}}$ & $3.97 \pm 0.35^{\mathrm{b}}$ & $3.31 \pm 0.4^{\mathrm{c}}$ \\
NEFA $(\mathrm{mM})$ & $4.63 \pm 0.33^{\mathrm{a}}$ & $3.62 \pm 0.29^{\mathrm{b}}$ & $5.68 \pm 0.65^{\mathrm{c}}$ \\
BHBA $(\mathrm{mM})$ & $0.35 \pm 0.01^{\mathrm{a}}$ & $0.38 \pm 0.23^{\mathrm{a}}$ & $0.73 \pm 0.05^{\mathrm{b}}$ \\
\hline
\end{tabular}

Different superscript letters indicate significant differences at $\mathrm{P}<0.05$ in the same line.

$\mathrm{C}$ - control group; L - low energy diet group; $\mathrm{H}$ - high energy diet group

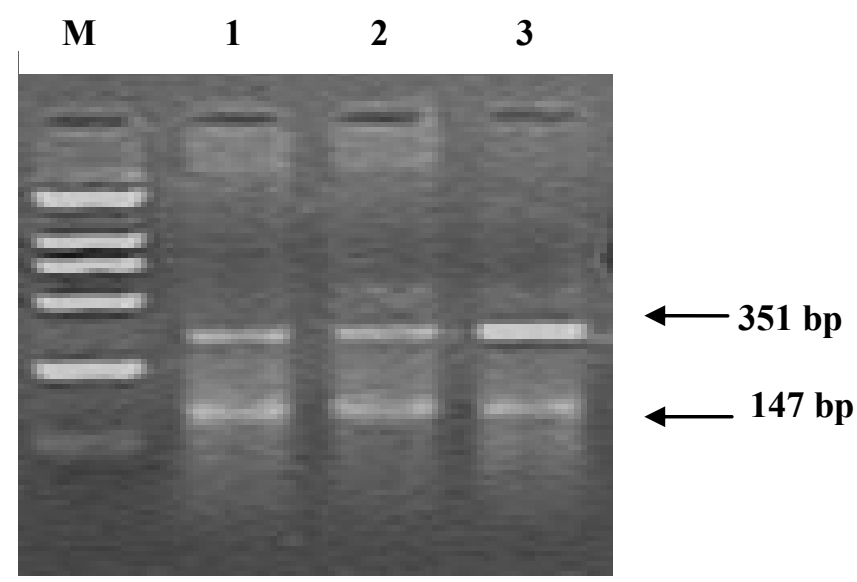

Fig. 1. PCR products of InsR in adipose tissues of different group dairy cows M - DL-2000 marker; 1 - high energy group, 2 - control group, 3 - low energy group 


\section{Discussion}

The transition from pregnancy to lactation in dairy cows involves extensive metabolic and endocrine changes to accommodate parturition and lactogenesis (6, 15). Energy demands during early lactation cannot be fulfilled entirely by dietary intake and, therefore, energy has to be mobilised from body reserves, mainly from adipose tissue (5). This process can result in increased circulating concentrations of NEFA and ketone bodies, and in a relatively low concentration of glucose (21). Glucose, NEFA, and BHBA are the key indexes of energy metabolic balance (25). On the basis of the results of this study, low energy diet during antepartum could alleviate the NEB of dairy cows postpartum. Contrarily, use of high energy diet at the antepartum period aggravated the NEB of dairy cows postpartum.

Insulin, which is secreted from pancreatic $\beta$-cells, plays a central role in the metabolism of mammals (4, 19). When INSR expression decreases, adipose tissues fail to respond effectively to circulating insulin (11). During NEB, decrease in both insulin and glucose levels, and elevated NEFA equally contribute to reduced insulin sensitivity $(8,18)$.

Insulin resistance in adipose tissue reduces the normal effects of insulin on lipid metabolism and results in a reduced uptake of circulating lipids and increased hydrolysis of stored triglycerides (20). Increased mobilisation of stored lipids in adipocytes elevates blood NEFA levels (11). Activation of the INSR in muscle and adipose tissue leads to an increase in the GLUT-4 on the surface of cells in these tissues, and therefore, it increases the rate of glucose entry into the cells (10). Imano et al. (9) have discovered that a decrease in the number of cell surface INSRs can cause insulin resistance. A study on the effects of NEFA and BHBA on the expression of INSR in bovine adipocytes cultured in vitro would help to define this problem in more detailed way.

Results of the study suggest that the high-energy diet at antepartum reduced the abundance of INSR mRNA in the adipose tissue of postpartum dairy cows, and increased adipose mobilisation, thereby further aggravating the NEB of cows. In contrast, feeding the low energy diet at antepartum increased the abundance of INSR mRNA in the adipose tissue of postpartum cows. This resulted in inhibition of fat mobilisation, promotion of glycogen synthesis, and maintenance of relatively constant blood glucose concentrations, thereby alleviating NEB. A decrease in INSR mRNA levels reduced the inhibitory effect of insulin on lipolysis in adipose tissue of dairy cows.

Summarising, in dairy cows fed a low energy diet at antepartum, INSR expression at postpartum increases, which may be beneficial for gluconeogenesis and lipogenesis and in compensating for the NEB that occurs in early lactation. Dairy cows fed a high energy diet at antepartum have decreased INSR expression in adipose tissue at postpartum, suggesting a possibility of reduction in responsiveness to insulin.
Acknowledgments: This study was supported by Program for New Century Excellent Talents in Heilongjiang Provincial University (1253-NCET-007).

\section{References}

1. Accorsi P.A., Govoni N., Gaiani R., Pezzi C., Seren E., Tamanini C.: Leptin, PRL, insulin and metabolic parameters throughout the dry period and lactation in dairy cows. Reprod Domest Anim 2005, 40, 217-223.

2. Civelek T., Aydin I., Cingi C.C., Yilmaz O., Kabu M.: Serum non-esterified fatty acids and $\beta$-hydroxybutyrate in dairy cows with retained placenta. Pak Vet J 2011, 31, 341-344.

3. Dohme-Meier F., Bee G.: Feeding unprotected CLA methyl esters compared to sunflower seeds increased milk CLA level but inhibited milk fat synthesis in cows. Asian-Aust J Anim Sci 2012, 25, 75-85.

4. Ferron M., Wei J.W., Yoshizawa T., Del Fattore A., DePinho R., Teti A., Ducy P., Karsenty G.: Insulin signaling in osteoblasts integrates bone remodeling and energy metabolism. Cell 2010, 142, 296-308.

5. Goff J.P., Horst R.L.: Physiological changes at parturition and their relationship to metabolic disorders. J Dairy Sci 1997, 80, 1260-1268.

6. Hachenberg S., Weinkauf C., Hiss S., Sauerwein H.: Evaluation of classification modes potentially suitable to identify metabolic stress in healthy dairy cows during the peripartal period. J Anim Sci 2007, 85, 1923-1932.

7. Hatonen K.A., Virtamo J., Eriksson J.G., Sinkko H.K., Sundvall J.E., Valsta L.M.: Protein and fat modify the glycaemic and insulinaemic responses to a mashed potato-based meal. Br J Nutr 2011, 22, 1-6.

8. Hayirli A.: The role of exogenous insulin in the complex of hepatic lipidosis and ketosis associated with insulin resistance phenomenon in postpartum dairy cattle. Vet Res Commun 2006, 30, 749-774.

9. Imano E., Kadowaki H., Kadowaki T.: Two patients with insulin resistance due to decreased levels of insulin-receptor mRNA. Diabetes 1991, 40, 548-557.

10. James D.E., Piper R.C.: Insulin resistance, diabetes, and the insulin-regulated trafficking of GLUT-4. J Cell Biol 1994, 126, 1123-1126.

11. Knott R.M., Trayhurn P., Hesketh J.E.: Changes in insulin-receptor mRNA levels in skeletal muscle and brown adipose tissue of weanling rats during fasting and refeeding. Br J Nutr 1992, 68, 583-592.

12. Liu G.W., Zhang Z.G., Wang J.G., Wang Z., Xu C., Zhu X.L.: Insulin receptor gene expression in normal and diseased bovine liver. J Comp Pathol 2010, 143, 258-261.

13. Liu G.W., Zhang Z.G., Zhu X.L., Wang Z., Xia C., Xu C.: A note on the distribution of insulin receptor mRNA in tissues of neonatal Holstein calves. J Anim feed Sci 2009, 18, 613-619.

14. MacLaren R., Cui W., Simard S., Cianflone K.: Influence of obesity and insulin sensitivity on insulin signaling genes in human omental and subcutaneous adipose tissue. J Lipid Res 2008, 49, 308-323.

15. Mohammadi M.C., Ghasrodashti A.R., Tamadon A., Behzadi M.A.: Effects of prepartum monensin feeding on energy metabolism and reproductive performance of postpartum high-producing Holstein dairy cows. Pak Vet J 2012, 32, 45-49. 
16. Prada P.O., Coelho M.S., Zecchin H.G., Dolnikoff M.S., Gasparetti A.L., Furukawa L.N., Saad M.J., Heimann J.C.: Low salt intake modulates insulin signaling, JNK activity and IRS- $1^{\text {ser307 }}$ phosphorylation in rat tissues. J Endocrinol 2005, 185, 429-437.

17. Razzaghi A., Aliarabi H., Tabatabaei M.M., Saki A.A., Valizadeh R., Zamani P.: Effect of dietary cation-anion difference during prepartum and postpartum periods on performance, blood, and urine minerals status of Holstein dairy cow. Asian-Aust J Anim Sci 2012, 25, 486-495.

18. Roden M., Price T., Perseghin G., Petersen K.F., Rothman D.L., Cline G.W., Shulman G.I.: Mechanism of free fatty acid-induced insulin resistance in humans. J Clin Invest 1996, 97, 2859-2865.

19. Sadri H., Bruckmaier R.M., Rahmani H.R., Ghorbani G.R., Morel I., Van Dorland H.A.: Gene expression of tumour necrosis factor and insulin signalling-related factors in subcutaneous adipose tissue during the dry period and in early lactation in dairy cows. J Anim Physiol Anim Nutr 2010, 94, E194-E202.

20. Thorn S.R., Ehrhardt R.A., Butler W.R., Quirk S.M., Boisclai Y.R.: Insulin regulates hepatic leptin receptor expression in early lactating dairy cows. Am J Physiol Regul Integr Comp Physiol 2008, 295, R1455-R1462.
21. Xu C., Wang Z., Zhang R.H., Fu S.X., Xia C.: Effect of NEFA and glucose levels on CPT-I mRNA expression and translation in cultured bovine hepatocytes. J Vet Med Sci 2011, 73, 97-101.

22. Zbylut J., Gehrke M., Malinowski E.: Relationship between postpartum disorders and pregnancy losses and subsequent fertility of dairy cows. Bull Vet Inst Pulawy 2012, 56, 287-292.

23. Zhang Z.G., Li X.B., Liu G.W., Chen Y.Y., Yu M.L., Wang J.G., Wang H.B., Liu L., Li Y.F., Gao L., Wang Z., Liu L., Zhu X.L.: Effect of short-term administration of glucagon on gene expression of the insulin receptor in primary cultured calf hepatocytes. Pak Vet J 2012, 32, 465-467.

24. Zhang Z.G., Li X.B., Liu G.W., Gao L., Guo C., Kong T., Wang H., Gao R., Wang Z., Zhu X.: High insulin concentrations repress insulin receptor gene expression in calf hepatocytes cultured in vitro. Cell Physiol Biochem 2011, 27, 637-640.

25. Zhang Z.G., Liu G.W., Li X.B., Wang Z., Kong T., Zhang N.S., Guo C.M.: $\beta$-hydroxybutyrate, glucose, calcium, phosphorus, and vitamin $\mathrm{C}$ concentration in blood of dairy cows with subclinical ketosis during the early lactation. Bull Vet Inst Pulawy 2009, 53, 71-74. 